\title{
National government to assume more responsibility for public hospitals in Australia
}

A ustralia's centre-left Labor government is pushing ahead with a sweeping package of reforms that would radically overhaul funding arrangements for the nation's public hospitals.

The plan would see the federal government assume primary responsibility for the cost of running Australia's public hospitals, which have historically been administered by the states and territories. It would also set new federal pricing and performance benchmarks, and make the Commonwealth of Australia responsible for the full cost of providing primary care and aged health services.

The reforms, which are currently being debated in Parliament, are the result of a two-year push by Prime Minister Julia Gillard and her predecessor, Kevin Rudd, to create a centralized set of prices and standards for the country's public health system. But critics worry that the reforms will add even more bureaucracy to an already complex system.

Australia has a relatively cost-effective health network. Per capita health spending has traditionally been about average for countries within the Organisation for Economic Cooperation and Development, above the United Kingdom but well below Canada and the United States.

However, the system is facing unprecedented pressure due to rising demand from above-average rates of population growth, mainly from immigration; an aging population; and growing community expectations for technologically-sophisticated treatments and cures.

Public hospital expenditure grew by nearly $10 \%$ per annum in the five years to 2007-08, according to the Australian Healthcare and Hospitals Association. Federal Treasury projections have warned that spending on health and aged care as a proportion of gross domestic product could nearly double by 2050 unless constraints are introduced.

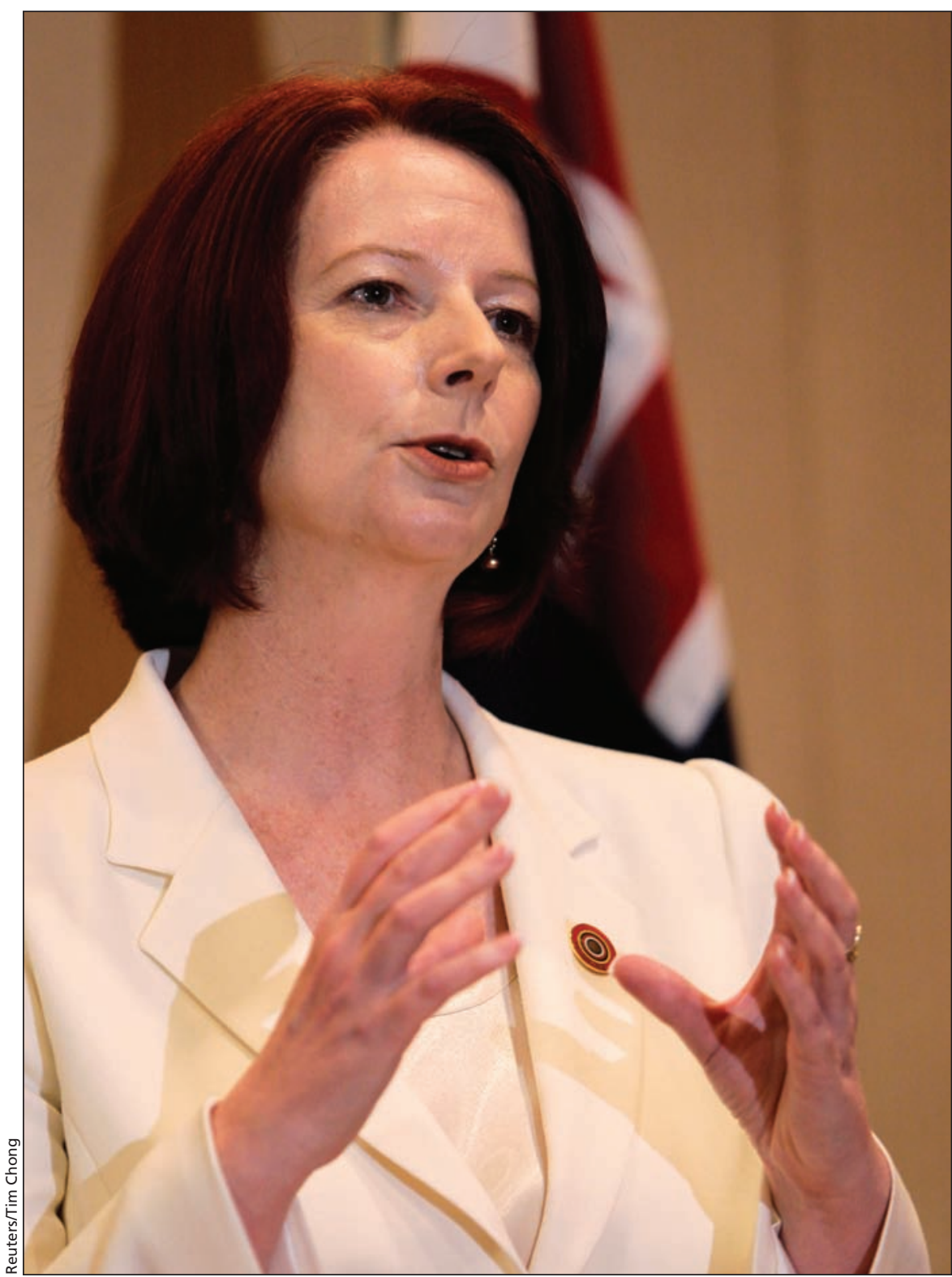

Australia's Prime Minister Julia Gillard says her nation's health system "has suffered from inadequate funding arrangments and unclear accountability for too long."

To that end, the government is seeking to establish a National Health and Hospitals Network that would bring the current fragmented, state-based system at least partially under the federal umbrella.

"Australia's health system has suffered from inadequate funding arrangements and unclear accountability for too long," Prime Minister Julia Gillard said as her government placed the reform package before Parliament.

Thus far, seven of Australia's eight states and territories have agreed to the government's plan, with only Western Australia refusing to participate. Nevertheless, the government has vowed to push ahead with the reforms. 
Under the new arrangement, the Commonwealth will assume $60 \%$ of the costs incurred in providing public hospital services to patients, as well as $60 \%$ of all capital costs and recurrent research or training expenditures undertaken in public hospitals. As of July 2011, it will also pay $100 \%$ of the cost of providing primary and aged care services.

The carrot for the states and territories is that they'll be relieved of $\mathrm{A} \$ 15.6$ billion Australian dollars in health care costs over the five fiscal years from 2014-15 to 2019-20. But there's also a stick: they'll have to hand over $30 \%$ of revenues they receive from Australia's goods and services tax.

The plan would see the establishment of localized hospital networks, where health and financial professionals on the ground would assume responsibility for administrative tasks. Hospitals would be reimbursed directly for each service they provide, rather than receiving population-based block grants from state health administrations. The government argues that the proposed perservice funding arrangement will help hospitals meet rising demand and reduce wait times for elective surgeries.

The plan will also set new national standards for public hospital services, such as maximum four-hour wait times in emergency departments. Two new federal bodies - the Independent Hospitals Pricing Authority and the National Performance Authority would be established to determine centralized costs and standards.

The government contends that the plan will provide better incentives for investing in primary and preventative care, and ultimately reduce hospital expenditures. The opposition conservative Liberal Party appears unconvinced, however, and has vowed to fight the reforms. "Labor's reform is deluded. Putting more and more bureaucrats on the public purse will not deliver better patient outcomes," Peter Dutton, the party's shadow minister for health, said in a press release (http://peterdutton .com.au/MediaHub/MediaReleases/tabid /75/articleType/ArticleView/articleId/139 /categoryId/5/Health-reform-begins-with -Bureaucracy.aspx).

Several health bodies, including the Consumers Health Forum of Australia and the Australian Healthcare and Hospitals Association, the voice of public hospitals and community health centres, have applauded the reforms.

"We see the innovations in the hospital and the primary health care sectors as being complementary," says Prue Power, executive-director of the associ- ation. "If the reform is to be real, rather than just administrative or financial reform, it has got to be patient-centred reform."

But if some aspects of the overhaul are passed in Parliament, and others are not, "it could undermine the effectiveness" of the whole, she adds.

The association, along with several independent experts, also express concerns that without clearly defined channels of communication between the new federal administrators, state officials and the local hospital networks, the government's plan runs the risk of making the system more top-heavy and complex.

"This will just compound the blame game, because we don't have a clearly defined role for these local networks, and we don't have a clearly defined residual role for the states, nor what is the new role for the federal government," says Robert Wells, the director of the Sydney-based Menzies Centre for Health Policy and the Action-based Australian Primary Health Care Research Institute.

"Clearly, you'll just have more layers of bureaucracy fighting with each other about who is responsible," Wells says. — Meraiah Foley, Sydney, Australia

CMAJ 2011.DOI:10.1503/cmaj.109-3751 